\title{
Yield performance of eight mungbean (Phaseolus radiatus) genotypes in two locations in Manggarai District, East Nusa Tenggara, Indonesia
}

\author{
YOSEP S. MAU ${ }^{1, w}$, VINSENSIUS F.Y. MADU, ${ }^{1,3, w,}$ A.S.S. NDIWA ${ }^{1}$, DAMIANUS ADAR ${ }^{1}$, YOSEFINA R.Y. GANDUT ${ }^{1}$ \\ ${ }^{1}$ Faculty of Agriculture, Universitas Nusa Cendana, Jl. Adisucipto, Penfui, Kupang 85148, East Nusa Tenggara, Indonesia. Tel./Fax. +62-380-881085, \\ remail: yosepmau@yahoo.com \\ ${ }^{2}$ Agriculture Department Office of West Manggarai District. Jl. Daniel Daeng Nabit, Kelurahan Wae Kelambu, Komodo, West Manggarai 86754, East \\ Nusa Tenggara, Indonesia. "email: yomavelaf@gmail.com
}

Manuscript received: 15 March 2017. Revision accepted: 11 April 2017.

\begin{abstract}
Mau YS, MadulVFY, Ndiwa ASS, Adar D, Gandut YRY. 2017. Yield performance of eight mungbean (Phaseolus radiatus) genotypes in two locations in Manggarai District, East Nusa Tenggara, Indonesia. Trop Drylands 1: 24-31. Mungbean [Phaseolus radiatus (L.) Wilczek] is among most important crops cultivated in arid and semi-arid regions. Yet, various genotypes of mungbean are available which might differ in yield productivity across locations. The objective of this study was to elucidate yield performance of eight mungbean genotypes at two locations representing different altitudes (i.e. Murai and Watu Baur) in Manggarai District, East Nusa Tenggara Province, Indonesia. A Randomized Block Design was employed consisting of 8 treatments, each with 3 replicates. The assigned treatments were eight mungbean genotypes consisting of one local cultivar and seven Indonesian released superior varieties. Observed variables included yield components and yield of mungbean. Data from each location was subjected to ANOVA, followed by a combined ANOVA involving data from both locations. A post hoc test of DMRT (5\%) was performed to compare the treatment means. The study results showed that genotype $\mathrm{x}$ location interaction significantly or highly significantly affected most of the observed variables, except plant height at flowering, plant height at harvest, productive branches plant ${ }^{-1}$ and 100 -seed weight. Vima- 1 and Murai were found to perform better than other genotypes in most yield components and yield traits in both locations. The highest mean seed yield over two locations was produced by Murai (991.87 $\left.\mathrm{g} \mathrm{plot}^{-1}\right)$ and Vima-1 $\left(967.90 \mathrm{~g} \mathrm{plot}^{-1}\right)$. Mean seed yield of all genotypes at Perak was $365.0 \mathrm{~g} \mathrm{plot}^{-1}$ while that in Watu Baur was $761.27 \mathrm{~g} \mathrm{plot}^{-1}$.
\end{abstract}

Keywords: Genotype, location, mungbean, performance, yield

\section{INTRODUCTION}

Mungbean [Phaseolus radiatus (L.) Wilczek], also known as green gram or golden gram, is a dryland arid and semi-arid pulse crop, mostly cultivated as the second crop after maize, rice, sorghum, etc. The crop is well known for its nutritional value and health benefits, and is also used as fodder. In addition to its high protein and carbohydrate contents (Kumar et al. 2014; Dahiya, et al. 2015), mungbean contains high levels of folate and iron (Keatinge et al. 2011). From the perspective of agro-ecology, mungbean is known as a soil nitrogen enhancing crop through its ability to fix atmospheric nitrogen via root rhizobial symbiosis (Graham and Vance 2003). These advantageous characters render the mungbean an important crop in the tropical and sub-tropical regions of the world, including Indonesia.

In the subsistent agriculture system of semi-arid region of East Nusa Tenggara (ENT) Province, Indonesia, mungbean plays an important role as an affordable dietary protein source as well as a cash crop to the farmers. Mungbean is known to be well adapted to the semi-arid growing condition such as in ENT Province. The short duration type of most mungbean cultivars (55-60 days) makes this crop more suitable to be planted in this region as the second crop after paddy rice or maize. The crop is also easy to manage, low chance of harvest failure, high economic value, and can be easily prepared for consumption.

ENT Province is one of the mungbean production centers in Indonesia. During the last few years, however, mungbean production in the province fluctuated significantly due to many factors. It was revealed in the data released by ENT Province Central Bureau of Statistics (2012) that total mungbean production in ENT in 2009 was 13,462 tons, which then decreased to only 6,985 tons in 2010 and increased again to 10,408 tons in 2011. In addition, the productivity of mungbean in the region is still low, with only about $0.9 \mathrm{t} \mathrm{ha}^{-1}$ seed yield (ENT Central Bureau of Statistics 2012). The fluctuation in mungbean production is mainly due to fluctuation in the planting area and unfavorable climatic conditions such as drought. Meanwhile, poor agricultural practices and the use of lowyielding varieties are the main contributors to low mungbean productivity in this province.

In addition to the above-mentioned problems in mungbean production and productivity, water shortage and foliar diseases such as Cercospora leaf spot, rust, powdery mildew, scab, and viruses are other factors that also contributed significantly to the low mungbean production (Chand et al. 2015; Gnanaraj et al. 2015; Kumar et al. 2017; Parihar et al. 2017). The use of superior varieties is, therefore, considered the most effective and efficient way of overcoming the above-mentioned mungbean production 
constraints. The use of superior varieties is cheaper, easily adopted by farmers, and environmentally friendly. The availability of high-yielding varieties coupled with resistance to foliar diseases and drought stress would be a significant contribution in preventing the crop from harvest failure and hence, increasing the farmer's income.

A number of superior mungbean varieties have been produced by Indonesian Legume and Tuber Crops Research Institute (ILETRI); however, these varieties have not been extensively cultivated by the farmers in ENT Province, especially in Manggarai District (one of the mungbean production centers in the province) due to lack of information and access to these varieties by the farmers. Further, irrespective of their release as superior varieties, in fact, these varieties have not been evaluated for yield performance in ENT Province, which has a unique climatic condition (a semi-arid type) compared to that of the rest of Indonesian provinces. Such varieties have only been evaluated mostly in Java and Sumatera Islands which have a more humid climatic condition. It is, therefore, necessary to evaluate the performance of these superior varieties in Manggarai District to ensure their adaptability to the region. The objective of this study was to elucidate the yield and yield components performances of Indonesian released superior mungbean varieties and a local cultivar in two locations in Manggarai District. The most suitable genotypes for each of the two locations were also determined in the present study.

\section{MATERIALS AND METHODS}

\section{Research location and design}

This research was conducted in the field in two locations during the dry season (June to September) 2013. The two locations were selected to represent mungbean production centers in the district and also to represent two different altitudes, i.e. the low altitude at Watu Baur Village, Reok Sub-District (32 $\mathrm{m}$ asl), and the medium altitude at Perak Village, Cibal Sub-District (745 m asl).

The assigned treatment was mungbean genotypes, consisting of one local cultivar of Manggarai District (Local Manggarai) and seven Indonesian released superior varieties (Vima-1, Murai, Perkutut, Kenari, Betet, Walet, and Kutilang) making up a total of 8 treatments. The experiment in each location was laid out in a Randomized Block Design with each treatment consisting of three replicates. In total, 24 experimental units were included in each growing location.

\section{Land preparation and crop planting}

In each growing location, the planting site was first cleared from weeds and woods before plowing. The planting site was then sub-divided into three blocks, each was $100 \mathrm{~cm}$ apart. Each block was further sub-divided into 8 plots of $3 \mathrm{~m} \mathrm{x} 2 \mathrm{~m}$ size with $50 \mathrm{~cm}$ distance between plots. In total, 24 planting plots were prepared in each growing location.

Mungbean seeds were planted about $3 \mathrm{~cm}$ depth inside the planting holes with a planting space of $40 \mathrm{~cm} \times 20 \mathrm{~cm}$. Two plants were maintained in each planting hole. Fertilizer was used in the form of a compound NPK with a dosage of $100 \mathrm{~kg} \mathrm{ha}^{-1}$, equal to $40 \mathrm{~g} \mathrm{plot}^{-1}$, applied at planting time. Irrigation was provided daily to meet approximately $70-80 \%$ field capacity during the crop growth and development. Weeding was done manually, and pests and diseases control were conducted mechanically and chemically using insecticide and fungicide sprays. Harvesting was carried out when almost all pods in each plant within the plot started to turn black or brown (depending on the genotype) and were easy to explode. Harvesting was done manually.

\section{Observed variables and data analysis}

Observed variables included plant height at flowering $(\mathrm{cm})$, harvesting date (DAP), number of productive branches plant ${ }^{-1}$, number of pod clusters plant ${ }^{-1}$, number of pods plant ${ }^{-1}$, pod weight plant $^{-1}, 100$-seed weight $(\mathrm{g})$, seed weight plant ${ }^{-1}(\mathrm{~g})$ and seed weight $\operatorname{plot}^{-1}(\mathrm{~g})$.

The observed data from each growing location was subjected to analysis of variance using Randomized Block Design approach. A homogeneity variance analysis was then conducted prior to a combined analysis of variance employing data from both locations to determine genotype by location interaction effect on the observed variables. A post hoc test of Duncan Multiple Range Test was also carried out to compare the treatment means. Analysis of variance was carried out using Genstat Version 12 (VSNi 2009).

\section{RESULTS AND DISCUSSION}

\section{The treatment effect on the observed variables}

We carried out a Bartlet test of homogeneity of variance involving data collected from the two locations prior to combined analysis of variance to determine the genotype by location interaction, and the single factors genotype and location effects on the observed variables. The effect of the treatment on the observed variables is presented in Table 1.

Table 1. Combined analysis of variance of yield component and yield variables of eight mungbean genotypes tested in two locations.

\begin{tabular}{|c|c|c|c|c|c|c|c|c|c|c|c|}
\hline \multirow{2}{*}{$\begin{array}{l}\text { Source of } \\
\text { Variation }\end{array}$} & \multirow[t]{2}{*}{ DF } & \multicolumn{10}{|c|}{ F-value (calculated) } \\
\hline & & $\begin{array}{c}\text { Plant } \\
\text { height at } \\
\text { flowering }\end{array}$ & $\begin{array}{c}\text { Plant } \\
\text { height at } \\
\text { harvest }\end{array}$ & $\begin{array}{c}\text { Harvesting } \\
\text { date }\end{array}$ & $\begin{array}{c}\text { Productive } \\
\text { branches } \\
\text { plant }^{-1}\end{array}$ & $\begin{array}{c}\text { Pod } \\
\text { clusters } \\
\text { plant }^{-1}\end{array}$ & $\begin{array}{c}\text { Pods } \\
\text { plant }^{-1}\end{array}$ & $\begin{array}{c}\text { Pod } \\
\text { weight } \\
\text { plant }^{-1}\end{array}$ & $\begin{array}{c}\text { 100-seed } \\
\text { weight }\end{array}$ & $\begin{array}{c}\text { Seed } \\
\text { weight } \\
\text { plant }^{-1}\end{array}$ & $\begin{array}{c}\text { Seed } \\
\text { weight } \\
\text { plot }^{-1}\end{array}$ \\
\hline Location (L) & 1 & $252.28^{* * *}$ & $243.23^{* *}$ & $690.22^{* *}$ & $0.90^{\mathrm{ns}}$ & $95.81^{* *}$ & $73.45^{* *}$ & $68.91^{* * *}$ & $101.67^{* *}$ & $73.62^{* *}$ & $594.93^{* *}$ \\
\hline Genotype (G) & 7 & $19.57^{* *}$ & $20.08^{* *}$ & $31.26^{* *}$ & $9.45^{* *}$ & $0.46^{\mathrm{ns}}$ & $1.10^{\mathrm{ns}}$ & $3.63^{*}$ & $1571.70^{* *}$ & $4.79^{*}$ & $5.32^{*}$ \\
\hline $\mathrm{G} \times \mathrm{L}$ & 7 & $1.19^{\mathrm{ns}}$ & $1.12^{\mathrm{ns}}$ & $36.54^{* *}$ & $0.31^{\mathrm{ns}}$ & $4.28^{* *}$ & $2.87^{*}$ & $4.36^{* *}$ & $0.62^{\text {ns }}$ & $4.88^{* * *}$ & $498.67^{* *}$ \\
\hline $\mathrm{CV}(\%)$ & & 6.93 & 7.02 & 3.91 & 9.44 & 13.14 & 12.27 & 10.82 & 2.68 & 11.33 & 10.7 \\
\hline
\end{tabular}

Note: DF: Degree of freedom, ${ }^{* *}$ highly significant $(\mathrm{P}<0.01),{ }^{*}$ significant $(\mathrm{P}<0.05),{ }^{\mathrm{n}}$ not significant $(\mathrm{P}>0.05)$. 
Results of pooled ANOVA (Table 1) show a varying treatment effect on the observed variables. Highly significant interaction effect of genotype $\mathrm{x}$ location was observed on harvesting date, pod clusters plant ${ }^{-1}$, pod weight plant ${ }^{-1}$, seed weight plant $^{-1}$, and seed weight plat $^{-1}$. The genotype $\mathrm{x}$ location interaction significantly affected pods plant $^{-1}$ but caused no effect on plant height at flowering and harvesting stages, productive branches plant 1 and 100-seed weight. Meanwhile, the single factor genotype significantly affected all observed variables except productive branches plant ${ }^{-1}$ while location significantly/highly significantly affected almost all of the observed variables except pod clusters plant ${ }^{-1}$ and pods plant $^{-1}$.

Significant effect on the interaction between genotype and location implies that the mungbean genotypes were not consistent in their ranks in the observed variables, where the ranks changed following the change of the growing location. The existence of genotype by location may also indicate a specific adaptation of a genotype in a specific location for a certain observed variable. Detailed descriptions of the observed variables are presented below.

\section{Plant height at flowering and harvesting stages}

Genotype by location caused no significant effect on the plant height at both flowering and harvesting stages but singly; either mungbean genotype or growing location significantly affected the traits. Data presented in Table 2 show that mean plant height at flowering stage differed significantly among the tested genotypes with Local Manggarai produced the highest $(74.5 \mathrm{~cm})$ and Vima-1 produced the shortest $(48.8 \mathrm{~cm})$ plant heights (Table 2). The same situation occurred at harvesting stage where Local Manggarai and Vima-1 produced, respectively, the highest and shortest plant heights. Besides, plant heights of other six genotypes ranged, respectively, from $54.6 \mathrm{~cm}$ to $68.5 \mathrm{~cm}$ at flowering stage and $55.2 \mathrm{~cm}$ to $69.1 \mathrm{~cm}$ at harvesting stage. The study results also demonstrated that the plant height of each genotype at harvesting was a bit higher but not substantially different from that at flowering, which may indicate the determinate growth type of the tested mungbean genotypes. Local Manggarai produced significantly higher plant height than the released superior varieties at both flowering and harvesting stages, which presumably indicates its unique genetic control in this trait, in addition to its good adaptation to the growing conditions as this local cultivar has been cultivated by farmers from generation to generation.

In addition to the genotypic effect, the growing environment/location also caused a highly significant effect $(\mathrm{P}<0.01)$ on mean plant height of the mungbean genotypes. It is revealed in Table 2 that mean plant height was higher when the mungbean genotypes were grown in Watu Batur (low altitude) as compared to Perak (medium altitude). This situation occurred in both flowering and harvesting stages, which may explain the effect of environmental conditions such as temperature, humidity and sunlight intensity on the mungbean plant height performance. Lower altitude such as Watu Baur (32 m asl) tends to have more optimum environmental conditions such as temperature $\left(27-29^{\circ} \mathrm{C}\right)$ and sunlight intensity (10-12 $\mathrm{hr}$ day $^{-1}$ ) that are likely more favorable for mungbean growth as a $\mathrm{C}_{3}$ plant type. The altitude influences both the temperature and sunlight intensity. The higher the altitude, the lower is the temperature and the sunlight intensity, and vice versa. Lower temperature and sunlight intensity will ultimately inhibit crop growth and development due to the reduced photosynthesis process, which in turn slows down the plant height increase. The growing conditions at Perak Village (medium altitude, $745 \mathrm{~m}$ asl) with a mean temperature of $18.3{ }^{\circ} \mathrm{C}$ and sunlight intensity of $8-10 \mathrm{hr}$ day $^{-1}$, presumably, are not quite favorable for the optimal growth as shown by the significantly lower plant height of the tested mungbean genotypes in this location.

Our research results also revealed a great variation in harvesting date among mungbean genotypes tested in the two locations (Table 2). The Indonesian released variety Vima-1 was harvested earlier at 57 days after planting (DAP) when cultivated at Watu Baur (low altitude) and at 61.3 DAP when cultivated at Perak (medium latitude), while Local Manggarai was harvested the latest, respectively, 81.0 DAP at Watu Baur and 92.7 DAP at Perak. The harvesting dates of Vima-1 (57 DAP at Watu Baur and 61 DAP at Perak, respectively) approximated that of its varietal description, i.e. $58 \mathrm{DAP}$, which may indicate the genotypic stability of this trait. The longer harvesting dates of Local Manggarai at both locations were in line with the experience of the local farmers who usually take approximately 3 months to get the local mungbean genotype harvested.

As with plant height, the harvesting dates of the tested genotypes at Perak (medium altitude) were also significantly higher than those at Watu Baur (low altitude). Again, this might have been caused by the differences in environmental conditions between the two growing locations, which ultimately affected the plant's age differently. When grown at Perak with an altitude of $745 \mathrm{~m}$

Table 2. Mean plant height $(\mathrm{cm})$ at flowering and harvesting stages of eight mungbean genotypes tested in two locations

\begin{tabular}{|c|c|c|c|c|}
\hline \multirow{2}{*}{$\begin{array}{c}\text { Genotype (G) } \\
\text { Lokal Manggarai }\end{array}$} & \multicolumn{2}{|c|}{$\begin{array}{l}\text { Plant height at } \\
\text { flowering stage } \\
(\mathrm{cm})\end{array}$} & \multicolumn{2}{|c|}{$\begin{array}{c}\text { Plant height at } \\
\text { harvesting stage } \\
(\mathrm{cm})\end{array}$} \\
\hline & 74.5 & $\mathrm{e}$ & 75.2 & e \\
\hline Murai & 59.0 & $\mathrm{bc}$ & 59.6 & $\mathrm{bc}$ \\
\hline Betet & 60.6 & $\mathrm{c}$ & 61.1 & $\mathrm{c}$ \\
\hline Vima-1 & 48.8 & $\mathrm{a}$ & 49.2 & $\mathrm{a}$ \\
\hline Perkutut & 55.2 & $\mathrm{bc}$ & 55.7 & $\mathrm{bc}$ \\
\hline Kutilang & 54.6 & b & 55.2 & $\mathrm{~b}$ \\
\hline Walet & 68.5 & d & 69.1 & $\mathrm{~d}$ \\
\hline Kenari & 57.8 & $\mathrm{bc}$ & 58.6 & $\mathrm{bc}$ \\
\hline Location (L) & Perak & $\begin{array}{l}\text { Watu } \\
\text { Baur } \\
\end{array}$ & Perak & $\begin{array}{l}\text { Watu } \\
\text { Baur }\end{array}$ \\
\hline & 45.6 & 74.1 & 46.0 & 75.0 \\
\hline Mean (L) & A & B & A & B \\
\hline
\end{tabular}

Note: Means within the same column or row with the same letter (s) are not significantly different at 0.05 DMRT. The capital letter indicates comparison within the same row while small letter indicates comparison within the same column 
asl., the mungbean crop tended to have low metabolism due to the lower daily temperature $\left(18{ }^{\circ} \mathrm{C}\right)$, which in turn slows down the crop harvesting date. On the other hand, when the mungbean genotypes were tested at low altitude at Watu Baur (32 $\mathrm{m}$ asl, $27-29{ }^{\circ} \mathrm{C}$ daily temperature), the genotypes' metabolism were, presumably, higher due to the higher temperature of the growing environment. This was in line with Poehlman (1978) in Rao et al. (2016) who suggested that mean temperature of $28-30{ }^{\circ} \mathrm{C}$ is the most optimum for mungbean.

\section{Number of productive branches plant ${ }^{-1}$, pod clusters plant $^{-1}$, and pods plant ${ }^{-1}$}

In contrast to harvesting date, the present study results demonstrated no significant effect of genotype by location on productive branches plant ${ }^{-1}$. The same situation was true for the single factor genotypic effect but the location significantly affected the trait. Mean performance of productive branches plant ${ }^{-1}$ is presented in Table 3 .

Data in Table 3 show that the evaluated mungbean genotypes produced around 1.2-1.8 productive branches plant ${ }^{-1}$ when grown at Perak, and the range was wider and differed significantly among genotypes (1.3-2.5 branches plant $^{-1}$ ) when the genotypes were grown in the low altitude location, Watu Baur. Again, the explanation for these results is related to the different growing conditions of the two locations.

Number of productive branches plant ${ }^{-1}$ in Perak was lower than that in Watu Baur since the higher altitude of Perak provides less favorable conditions to the productive branches production as compared to that in the low altitude Watu Baur. When grown in Watu Baur, Murai performed the best with 2.5 productive branches plant ${ }^{-1}$ but was not significantly different from Vima-1. Kutilang, on the other hand, produced the lowest number of productive branches plant $^{-1}$ (1.3) at each of both locations. The high number of productive branches plant ${ }^{-1}$ exhibited by both Murai and Vima- 1 is supported by the more favorable conditions of low altitude growing location at Watu Baur. The crop growth and development is frequently influenced by both genetic and environmental factors so that the growth and yield performances are strongly determined by the genetic makeup of the crop and the growing conditions. The genetic potential of a crop genotype is frequently not fully expressed due to the environmental effect and, therefore, performances of some genotypes may be altered by the changing growing environments. Welsh and Mogea (1991) stated that if the difference in performance of two genotypes within the same environment can be measured, then the difference between the two genotypes results from genotypic variation that exists between the two genotypes. Furthermore, according to Allard (1992), the observed phenotypic variation expressed in the same environment does occur because the crops possess different genetic backgrounds.

Our results revealed highly significant effect $(\mathrm{P}<0.01)$ of both genotypes by location and location on the number of pod clusters plant ${ }^{-1}$ while the genotype alone caused no significant effect on the trait. The existence of significant genotype by location interaction effect implies changes in the rank of pod clusters plant ${ }^{-1}$ of the mungbean genotypes when grown in different locations. Mean pod clusters plant ${ }^{-}$ ${ }^{1}$ presented in Table 3 shows high variation over the two growing locations. Pod clusters plant ${ }^{-1}$ of most genotypes was higher in Watu Baur as compared to Perak. The highest pod cluster plant $^{-1}$ was produced by Murai (7.8 clusters) but was not substantially different from that of Betet (7.0), Kenari (6.8) and Vima-1 (6.7). By location, mean pod clusters plant ${ }^{-1}$ at Watu Baur was significantly higher than that at Perak.

Table 3. Mean harvesting date (DAP), productive branches plant ${ }^{-1}$, pod clusters plant ${ }^{-1}$ and pods plant ${ }^{-1}$ of eight mungbean genotypes tested in two locations

\begin{tabular}{|c|c|c|c|c|c|c|c|c|c|c|c|c|}
\hline \multirow{3}{*}{ Genotype (G) } & \multirow{2}{*}{\multicolumn{3}{|c|}{$\begin{array}{c}\begin{array}{c}\text { Harvesting date } \\
\text { (DAP) }\end{array} \\
\text { Location (L) }\end{array}$}} & \multirow{2}{*}{\multicolumn{2}{|c|}{$\begin{array}{c}\begin{array}{c}\text { Productive branches } \\
\text { plant }^{-1}\end{array} \\
\text { Location }(\mathbf{L}) \\
\end{array}$}} & \multicolumn{4}{|c|}{ Pod clusters plant ${ }^{-1}$} & \multicolumn{3}{|c|}{ Pods plant $^{-1}$} \\
\hline & & & & & & & Location & & & & Location (1) & \\
\hline & Perak & Watu Baur & Mean (G) & Perak & Watu Baur & Perak & Watu Baur & Mean & (G) & Perak & Watu Baur & Mean (G) \\
\hline Local Manggarai & $\begin{array}{c}92.7 \mathrm{f} \\
\mathrm{B}\end{array}$ & $\begin{array}{c}81.0 \mathrm{f} \\
\mathrm{A}\end{array}$ & $86.8 \mathrm{e}$ & $1.3 \mathrm{a}$ & $1.5 \mathrm{ab}$ & $\begin{array}{c}5.2 \mathrm{~b} \\
\mathrm{~A}\end{array}$ & $\begin{array}{c}5.5 \mathrm{ab} \\
\mathrm{A}\end{array}$ & 5.4 & $\mathrm{a}$ & $\begin{array}{c}17.2 \mathrm{~b} \\
\mathrm{~A}\end{array}$ & $\begin{array}{c}22.0 \mathrm{~b} \\
\mathrm{~B}\end{array}$ & $19.6 \mathrm{a}$ \\
\hline Murai & $\begin{array}{c}73.7 \mathrm{~d} \\
\mathrm{~B}\end{array}$ & $\begin{array}{c}63.0 \mathrm{e} \\
\mathrm{A}\end{array}$ & $68.3 \mathrm{~d}$ & $1.8 \mathrm{a}$ & $2.5 \mathrm{e}$ & $\begin{array}{c}4.0 \mathrm{ab} \\
\mathrm{A}\end{array}$ & $\begin{array}{c}7.8 \mathrm{~d} \\
\mathrm{~B}\end{array}$ & 59 & $\mathrm{a}$ & $\begin{array}{c}14.9 \mathrm{ab} \\
\mathrm{A}\end{array}$ & $\begin{array}{c}24.4 \mathrm{bc} \\
\mathrm{B}\end{array}$ & $19.6 \mathrm{a}$ \\
\hline Betet & $\begin{array}{c}68.7 \mathrm{c} \\
\mathrm{B}\end{array}$ & $\begin{array}{c}60.0 \mathrm{c} \\
\mathrm{A}\end{array}$ & $64.3 \mathrm{bcd}$ & $1.4 \mathrm{a}$ & $1.8 \mathrm{bcd}$ & $\begin{array}{c}3.6 \mathrm{a} \\
\mathrm{A}\end{array}$ & $\begin{array}{c}7.0 \mathrm{~cd} \\
\mathrm{~B}\end{array}$ & 5.3 & $\mathrm{a}$ & $\begin{array}{c}10.9 \mathrm{a} \\
\mathrm{A}\end{array}$ & $\begin{array}{c}22.5 \mathrm{bc} \\
\mathrm{B}\end{array}$ & $16.7 \mathrm{a}$ \\
\hline Vima-1 & $\begin{array}{c}61.3 \mathrm{a} \\
\mathrm{B}\end{array}$ & $\begin{array}{c}57.0 \mathrm{a} \\
\mathrm{A}\end{array}$ & $59.2 \mathrm{a}$ & $1.6 \mathrm{a}$ & $2.1 \mathrm{de}$ & $\begin{array}{c}3.7 \mathrm{a} \\
\mathrm{A}\end{array}$ & $\begin{array}{l}6.7 \mathrm{bcd} \\
\text { B }\end{array}$ & 5.2 & $\mathrm{a}$ & $\begin{array}{c}12.0 \mathrm{a} \\
\mathrm{A}\end{array}$ & $\begin{array}{c}26.1 \mathrm{c} \\
\mathrm{B}\end{array}$ & $19.1 \mathrm{a}$ \\
\hline Perkı & $\begin{array}{c}66.7 \mathrm{~b} \\
\mathrm{~B}\end{array}$ & $\begin{array}{c}60.0 \mathrm{c} \\
\mathrm{A}\end{array}$ & $63.3 \mathrm{abc}$ & $1.5 \mathrm{a}$ & $2.0 \mathrm{~cd}$ & $\begin{array}{c}4.1 \mathrm{ab} \\
\mathrm{A}\end{array}$ & $\begin{array}{c}6.4 \mathrm{bc} \\
\mathrm{B}\end{array}$ & 5.2 & $\mathrm{a}$ & $\begin{array}{c}13.4 \mathrm{ab} \\
\mathrm{A}\end{array}$ & $\begin{array}{c}22.6 \mathrm{bc} \\
\mathrm{B}\end{array}$ & $18.0 \mathrm{a}$ \\
\hline Kutilang & $\begin{array}{c}74.3 \mathrm{de} \\
\text { B }\end{array}$ & $\begin{array}{c}61.3 \mathrm{~d} \\
\mathrm{~A}\end{array}$ & $67.8 \mathrm{~cd}$ & $1.2 \mathrm{a}$ & $1.3 \mathrm{a}$ & $\begin{array}{c}3.8 \mathrm{a} \\
\mathrm{A}\end{array}$ & $\begin{array}{c}5.0 \mathrm{a} \\
\mathrm{A}\end{array}$ & 4.5 & $\mathrm{a}$ & $\begin{array}{c}12.4 \mathrm{a} \\
\mathrm{A}\end{array}$ & $\begin{array}{c}10.0 \mathrm{a} \\
\mathrm{B}\end{array}$ & $15.1 \mathrm{a}$ \\
\hline Walet & $\begin{array}{c}66.3 \mathrm{~b} \\
\mathrm{~B}\end{array}$ & $\begin{array}{c}58.3 \mathrm{~b} \\
\mathrm{~A}\end{array}$ & $62.3 \mathrm{ab}$ & $1.4 \mathrm{a}$ & $1.7 \mathrm{abc}$ & $\begin{array}{c}4.3 \mathrm{ab} \\
\mathrm{A}\end{array}$ & $\begin{array}{l}6.2 \mathrm{abc} \\
\mathrm{B}\end{array}$ & 5.2 & $\mathrm{a}$ & $\begin{array}{c}13.4 \mathrm{ab} \\
\mathrm{A}\end{array}$ & $\begin{array}{c}23.6 \mathrm{bc} \\
\mathrm{B}\end{array}$ & $18.5 \mathrm{a}$ \\
\hline Kenari & $\begin{array}{c}75.0 \mathrm{e} \\
\mathrm{B}\end{array}$ & $\begin{array}{c}62.7 \mathrm{e} \\
\mathrm{A}\end{array}$ & $68.8 \mathrm{~d}$ & $1.6 \mathrm{a}$ & $2.0 \mathrm{~cd}$ & $\begin{array}{c}4.1 \mathrm{ab} \\
\mathrm{A}\end{array}$ & $\begin{array}{c}6.8 \mathrm{bcd} \\
\text { B }\end{array}$ & 5.4 & $\mathrm{a}$ & $\begin{array}{c}12.5 \mathrm{a} \\
\mathrm{A}\end{array}$ & $\begin{array}{c}20.9 \mathrm{ab} \\
\mathrm{B}\end{array}$ & 16.7 \\
\hline lean $(\mathrm{L})$ & $72.3 \mathrm{~B}$ & $62.9 \mathrm{~A}$ & & & & $4.1 \mathrm{~A}$ & $6.4 \mathrm{~B}$ & & & $13.3 \mathrm{~A}$ & $22.5 \mathrm{~B}$ & \\
\hline
\end{tabular}

Note: Means within the same coloumn or row with the same letter (s) are not significantly different at 0.05 DMRT. The capital letter indicates comparison within the same row while small letter indicates comparison within the same column. 
Combined analysis of variance of pods plant ${ }^{-1}$ showed highly significant differences among locations (Table 3). The present study results are in line with previous studies by Ullah et al. (2011), Raturi et al. (2012) and Alia et al. (2014), who observed highly significant location and genotype by location interaction effects on pods plant ${ }^{-1}$ of mungbean. Data in Table 3 reveal that mean pods plant ${ }^{-1}$ of all genotypes at Watu Baur was about two folds that of Perak. Vima-1 produced the highest number of pods plant ${ }^{-1}$ (26 pods) but was not significantly deviated from that of Murai (24.4), Walet (23.6), Perkutut (22.6), and Betet (22.5). These results might have happened due to fact that these varieties are superior varieties that possess the capacity to make use of the available growth factors resources to increase their photosynthesis process before and during flowering stages to support high rate flower formation, which then resulted in high number pod formation. The fact that these varieties, particularly Murai and Vima-1, also produced the highest productive branches plant $^{-1}$ might have also contributed to the high pods plant ${ }^{-1}$ of these varieties.

\section{Pod weight plant $^{-1}$ and seed weight plant $^{-1}$}

The present study results revealed high variation of pod weight plant ${ }^{-1}$ among the tested mungbean genotypes. Like number of branches plant ${ }^{-1}$, number of clusters plant ${ }^{-1}$ and number of pods plant ${ }^{-1}$, the Indonesian released varieties Murai and Vima-1 also produced the highest pod weight plant $^{-1}$, respectively, $27.19 \mathrm{~g}$ and $27.00 \mathrm{~g}$ (Table 4), both were produced at Watu Baur. Meanwhile, Local Manggarai and Betet performed the poorest in this trait with only about, respectively, $9.8 \mathrm{~g}$ and $9.5 \mathrm{~g} \mathrm{plant}^{-1}$ when grown at Perak. Similar to other traits, mean pod weight of all genotypes at Watu Baur was higher than that at Perak, which implies more favorable growing environment conditions at the first location to support optimal pod weight production as compared to the latter. Over two locations, Murai and Vima-1 performed the best with, respectively, 21.9 and $21.0 \mathrm{~g}$ plant $^{-1}$ while Local Manggarai performed the poorest with only $11.3 \mathrm{~g} \mathrm{plant}^{-1}$ (Table 3 ). These findings were supported by Welsh and Mogea (1991) who stated that each crop genotype has a physiologically unique production capacity that is determined by energy, climate, soil nutrients, humidity, and other growth factor variabilities, which then through their interaction with the genetic capacity of the crop will develop the adaptation capability of the crop in increasing its growth and yield performances.

We also found in the present study that seed weight plant $^{-1}$ also varied greatly among mungbean genotypes as presented in Table 4. Seed weight of the mungbean genotypes ranged from 5.95-23.68 $\mathrm{g}$ plant $^{-1}$ with Murai and Vima-1 consistently performed the best when grown at Watu Baur. This implies that these two Indonesian released varieties are the best performers in terms of seed production, which is also supported by their best performances in yield supporting component traits. Mean seed yield plant ${ }^{-1}$ of all genotypes at Watu Baur was two folds that of Perak, which implies better environmental conditions at Watu Baur to support the crop growth and seed yield production. Meanwhile, the mean seed yields of the genotypes over two locations also varied considerably with a range of 8.04 to $18.27 \mathrm{~g} \mathrm{plant}^{-1}$. Again, Murai and Vima-1 performed the best over two locations while Local Manggarai performed the poorest. It is interesting to note in this study that despite its long adaptation to the environment in the region, Local Manggarai was still left behind by most of the Indonesian released varieties in terms of seed yield production. This presumably caused mainly by the genetic background of the tested genotypes. Most of the superior varieties had been developed in such a way that all necessary genes are combined to support high yield production and the local cultivar, on the other hand, may only be able to undergo natural processes to develop its production capacity, which is very much unlikely to occur maximally in a short time.

\section{0-seed weight and seed weight plot $^{-1}$}

We observed no significant effect of genotype by location interaction on 100-seed weight; however, each of the single factors Genotype and Location highly significantly affected the trait (Table 1). This implies that 100 -seed weights of genotypes included in the present study are mostly determined by the genetic factor, and expression of this genetic factor is not influenced by the change in the growing environmental conditions. Previous studies (Ullah et al. 2011; Raturi et al. 2012; Alia et al. 2014) also found a highly significant effect of either genotype or location on the trait but the effect of genotype by location interaction was not significant on the 100-seed weight of mungbean. Meanwhile, Somta et al. (2015) found six quantitative trait loci (QTLs) that were related to 100-seed weight in mungbean genotypes grown in rainy and dry seasons, however, the number of QTLs detected was substantially affected by day length, which implies that seed weight is also determined by the environmental factor.

Data presented in Table 5 shows quite a wide range of 100 -seed weight from 3.13 to $7.97 \mathrm{~g}$. The superior variety Kutilang, in contrast to its poor performances in other observed traits, performed the best with a mean 100-seed weight of $7.81 \mathrm{~g}$ over two locations, which differed significantly from that of other genotypes. Local Manggarai performed the poorest with only $3.35 \mathrm{~g} 100-\mathrm{seed}^{-1}$. The high 100-seed weight of Kutilang implies that this genotype possesses larger seed size than other genotypes. 100-seed weight is positively correlated with seed size, and seed size itself is also determined by pod size. Small pod size produces small seed size due to the narrow pod wall size that limits the seed cell development.

Like other traits, the mean 100-seed weight of all genotypes at Watu Baur was higher than that at Perak. More favorable environmental conditions at Watu Baur is the plausible explanation for this finding. Favorable environmental conditions at Watu Baur enabled the crop to undergo optimal photosynthesis process. Photosynthesis process is strongly influenced by environmental factors such as sunlight intensity, soil nutrient availability, $\mathrm{CO}_{2}$, humidity, etc. If these environmental elements are optimally utilized by the plant, then the photosynthesis process will be more optimal in accumulating dry matter/assimilate production (Rao et al. 2016). 
Table 4. Mean pod weight plant ${ }^{-1}(\mathrm{~g})$ and seed weight plant $^{-1}(\mathrm{~g})$ of eight mungbean genotypes tested at two locations

\begin{tabular}{|c|c|c|c|c|c|c|c|c|c|c|c|c|}
\hline \multirow{3}{*}{ Genotype (G) } & \multicolumn{6}{|c|}{ Pod weight plant $^{-1}$ (g) } & \multicolumn{6}{|c|}{ Seed weigth plant $^{-1}(\mathrm{~g})$} \\
\hline & \multicolumn{4}{|c|}{ Location (E) } & \multicolumn{8}{|c|}{ Location (E) } \\
\hline & \multicolumn{2}{|l|}{ Perak } & \multicolumn{2}{|c|}{ Watu Baur } & \multicolumn{2}{|c|}{ Mean (G) } & \multicolumn{2}{|l|}{ Perak } & \multicolumn{2}{|c|}{ Watu Baur } & \multicolumn{2}{|c|}{ Mean (G) } \\
\hline \multirow[t]{2}{*}{ Local Manggarai } & 9.76 & $\mathrm{a}$ & 12.86 & $\mathrm{a}$ & 11.31 & $\mathrm{a}$ & 6.38 & $\mathrm{a}$ & 9.69 & $\bar{a}$ & 8.04 & $\mathrm{a}$ \\
\hline & A & & A & & & & A & & B & & & \\
\hline \multirow[t]{2}{*}{ Murai } & 16.69 & $\mathrm{c}$ & 27.19 & $\mathrm{e}$ & 21.94 & $\mathrm{c}$ & 12.85 & $\mathrm{~b}$ & 23.68 & $\mathrm{e}$ & 18.27 & $\mathrm{c}$ \\
\hline & A & & B & & & & A & & $\mathrm{B}$ & & & \\
\hline \multirow[t]{2}{*}{ Betet } & 9.52 & $\mathrm{a}$ & 20.47 & $\mathrm{bc}$ & 15.00 & $a b$ & 5.95 & $\mathrm{a}$ & 16.65 & $\mathrm{~b}$ & 11.30 & $a b$ \\
\hline & A & & B & & & & A & & B & & & \\
\hline \multirow[t]{2}{*}{ Vima-1 } & 15.02 & $\mathrm{c}$ & 27.00 & $\mathrm{e}$ & 21.01 & $\mathrm{c}$ & 12.47 & $\mathrm{~b}$ & 22.99 & $\mathrm{e}$ & 17.73 & $\mathrm{c}$ \\
\hline & $\mathrm{A}$ & & $\mathrm{B}$ & & & & $\mathrm{A}$ & & $\mathrm{B}$ & & & \\
\hline \multirow[t]{2}{*}{ Perkutut } & 14.03 & bc & 23.59 & $\mathrm{~cd}$ & 18.81 & $\mathrm{bc}$ & 10.04 & $\mathrm{~b}$ & 19.55 & $\mathrm{~cd}$ & 14.80 & $\mathrm{bc}$ \\
\hline & A & & B & & & & A & & B & & & \\
\hline \multirow[t]{2}{*}{ Kutilang } & 14.84 & $\mathrm{c}$ & 19.12 & $\mathrm{~b}$ & 16.98 & $\mathrm{bc}$ & 10.36 & $\mathrm{~b}$ & 15.58 & $\mathrm{~b}$ & 12.97 & $\mathrm{~b}$ \\
\hline & A & & B & & & & A & & B & & & \\
\hline \multirow[t]{2}{*}{ Walet } & 10.82 & $a b$ & 20.95 & bcd & 15.89 & $a b$ & 7.46 & $\mathrm{a}$ & 17.07 & bc & 12.26 & $a b$ \\
\hline & A & & B & & & & A & & B & & & \\
\hline \multirow[t]{2}{*}{ Kenari } & 14.71 & $\mathrm{c}$ & 24.22 & de & 19.47 & $\mathrm{bc}$ & 10.20 & $\mathrm{~b}$ & 19.94 & $\mathrm{~d}$ & 15.07 & $\mathrm{bc}$ \\
\hline & A & & B & & & & B & & B & & & \\
\hline Mean $(\mathbf{L})$ & 13.17 & $\mathbf{A}$ & 21.93 & B & & & 9.46 & $\mathbf{A}$ & 18.14 & B & & \\
\hline
\end{tabular}

Note: Means within the same coloumn or row with the same letter (s) are not significantly different at 0.05 DMRT. The capital letter indicates comparison within the same row while small letter indicates comparison within the same column

Table 5. Mean 100-seed weight and seed weight plot $^{-1}$ of eight mungbean genotypes tested in two locations

\begin{tabular}{|c|c|c|c|c|c|c|c|c|c|c|c|c|}
\hline \multirow{3}{*}{ Genotype (G) } & \multicolumn{6}{|c|}{ 100-seed weight (g) } & \multicolumn{6}{|c|}{ Seed weight plot ${ }^{-1}$ (g) } \\
\hline & \multicolumn{4}{|c|}{ Location (L) } & \multicolumn{8}{|c|}{ Location (L) } \\
\hline & Perak & & Watu Bat & & $\operatorname{Mean}(\mathbf{G})$ & & Perak & & Watu Baur & & Mean (G) & \\
\hline Local Manggarai & $\begin{array}{r}3.13 \\
\mathrm{~A}\end{array}$ & $\mathrm{a}$ & $\begin{array}{r}3.56 \\
\mathrm{~A}\end{array}$ & $\mathrm{a}$ & 3.35 & $\mathrm{a}$ & $\begin{array}{r}242.73 \\
\mathrm{~A}\end{array}$ & $\mathrm{a}$ & $\begin{array}{r}405.03 \\
\mathrm{~B}\end{array}$ & $\mathrm{a}$ & 323.88 & $\mathrm{a}$ \\
\hline Murai & $\begin{array}{r}6.82 \\
\mathrm{~A}\end{array}$ & a & $\begin{array}{r}7.16 \\
\text { A }\end{array}$ & $\mathrm{a}$ & 6.99 & $\mathrm{e}$ & $\begin{array}{r}493.16 \\
\mathrm{~A}\end{array}$ & $\mathrm{f}$ & $\begin{array}{r}991.87 \\
\text { B }\end{array}$ & g & 742.51 & $\mathrm{c}$ \\
\hline Betet & $\begin{array}{r}5.83 \\
\mathrm{~A}\end{array}$ & $\mathrm{a}$ & $\begin{array}{r}6.23 \\
\mathrm{~A}\end{array}$ & $\mathrm{a}$ & 6.03 & $\mathrm{~b}$ & $\begin{array}{r}233.34 \\
\mathrm{~A}\end{array}$ & $\mathrm{a}$ & $\begin{array}{r}695.55 \\
\mathrm{~B}\end{array}$ & $\mathrm{c}$ & 464.45 & $a b$ \\
\hline Vima-1 & $\begin{array}{r}6.29 \\
\mathrm{~A}\end{array}$ & $\mathrm{a}$ & $\begin{array}{r}6.65 \\
\mathrm{~A}\end{array}$ & $\mathrm{a}$ & 6.47 & $\mathrm{~d}$ & $\begin{array}{r}481.85 \\
\mathrm{~A}\end{array}$ & $\mathrm{e}$ & $\begin{array}{r}967.90 \\
\text { B }\end{array}$ & g & 724.88 & $\mathrm{c}$ \\
\hline Perkutut & $\begin{array}{r}6.11 \\
\mathrm{~A}\end{array}$ & $\mathrm{a}$ & $\begin{array}{r}6.55 \\
\mathrm{~A}\end{array}$ & $\mathrm{a}$ & 6.33 & $\mathrm{c}$ & $\begin{array}{r}385.81 \\
\mathrm{~A}\end{array}$ & $\mathrm{c}$ & $\begin{array}{r}817.94 \\
\text { B }\end{array}$ & $\mathrm{e}$ & 601.87 & $\mathrm{bc}$ \\
\hline Kutilang & $\begin{array}{r}7.66 \\
\mathrm{~A}\end{array}$ & $\mathrm{a}$ & $\begin{array}{r}7.97 \\
\mathrm{~A}\end{array}$ & $\mathrm{a}$ & 7.81 & $\mathrm{~g}$ & $\begin{array}{r}400.78 \\
\mathrm{~A}\end{array}$ & $\mathrm{~d}$ & $\begin{array}{r}659.57 \\
\text { B }\end{array}$ & $\mathrm{b}$ & 530.17 & $\mathrm{~b}$ \\
\hline Walet & $\begin{array}{r}7.14 \\
\mathrm{~A}\end{array}$ & $\mathrm{a}$ & $\begin{array}{r}7.66 \\
\text { A }\end{array}$ & $\mathrm{a}$ & 7.40 & $\mathrm{f}$ & $\begin{array}{r}287.04 \\
\mathrm{~A}\end{array}$ & $\mathrm{~b}$ & $\begin{array}{r}719.44 \\
\text { B }\end{array}$ & d & 503.24 & $a b$ \\
\hline Kenari & $\begin{array}{r}6.71 \\
\text { B }\end{array}$ & $\mathrm{a}$ & $\begin{array}{r}7.15 \\
\mathrm{~A}\end{array}$ & $\mathrm{a}$ & 6.93 & $\mathrm{e}$ & $\begin{array}{r}395.53 \\
\mathrm{~A}\end{array}$ & $\mathrm{~cd}$ & $\begin{array}{r}832.83 \\
\text { B }\end{array}$ & $f$ & 614.18 & $\mathrm{bc}$ \\
\hline $\operatorname{Mean}(\mathbf{L})$ & 6.21 & $\mathbf{A}$ & 6.62 & B & & & 365.03 & $\mathbf{A}$ & 761.27 & B & & \\
\hline
\end{tabular}

Note: Means within the same column or row with the same letter (s) are not significantly different at 0.05 DMRT. The capital letter indicates comparison within the same row while small letter indicates comparison within the same column

In contrast to 100-seed weight, our study results revealed that genotype by location interaction highly significantly affected seed weight per plot and so did the effect of single factor Location. Meanwhile, the single factor Genotype affected the trait significantly (Table 1). The existence of genotype by location interaction effect demonstrates inconsistent genotype performances across the changing environments (Ullah et al. 2011). In this regard, seed weight per plot is controlled by genetic factors and the effect of this genetic factor changed according to the location where the mungbean genotypes are grown.
This might have occurred since each genotype responded differently to the changing environment that resulted in variable seed production per plot.

Data in Table 5 show that seed weight plot $^{-1}$ of the tested mungbean genotypes ranged from 233.34 to 991.87 $\mathrm{g}$, and the seed weight plot $^{-1}$ of all genotypes grown at Watu Baur was two folds that at Perak. Similar to seed weight plant ${ }^{-1}$ and other seed yield supporting traits, Murai and Vima-1 produced the highest seed yield plot $^{-1}$ when grown at Watu Baur with, respectively, $991.87 \mathrm{~g} \mathrm{plot}^{-1}$ and $967.90 \mathrm{~g} \mathrm{plot}^{-1}$. Mean seed weight plot $^{-1}$ of Murai and 
Vima-1 over the two locations were also the highest with, respectively, $742.51 \mathrm{~g}$ and $724.88 \mathrm{~g} \mathrm{plot}^{-1}$. These findings indicated that the two Indonesian released superior varieties, i.e. Murai and Vima-1 are the best high-yielding mungbean varieties for the region.

The high seed yield performances of Murai and Vima-1 are supported by their performances in yield supporting traits such as number of productive branches plant ${ }^{-1}$, number of pod clusters plant ${ }^{-1}$, number of pods plant $^{-1}$, pod weight plant $^{-1}$ and seed weight plant $^{-1}$, where these two varieties consistently performed much better than other genotypes. A previous study by Hakim and Suyamto (2012) reported that seed yield of mungbean is significantly and positively correlated with number of pods plant ${ }^{-1}$, number of seeds pod $^{-1}$, seed yield plant ${ }^{-1}$ and 100-seed weight. Significant and positive correlation between seed yield of mungbean with each of yield component characters such as number of seed $\operatorname{pod}^{-1}$, number of pods plant ${ }^{-1}$, number of pods cluster plant ${ }^{-1}$, number of pods cluater ${ }^{-1}$, days to $50 \%$ flowering, days to maturity was also reported by Om and Singh (2016).

Seed yield production of Murai was $991.87 \mathrm{~g} \mathrm{pot}^{-1}$ (equals to $2.48 \mathrm{t} \mathrm{ha}^{-1}$ ) and that of Vima-1 was $967.90 \mathrm{~g}$ plot $^{-1}$ ( equals to $2.42 \mathrm{t} \mathrm{ha}^{-1}$ ). Meanwhile, mean seed yields of Murai and Vima-1 as described in their varietal descriptions are, respectively, $1.5 \mathrm{t} \mathrm{ha}^{-1}$ and $1.76 \mathrm{t} \mathrm{ha}^{-1}$ (Suhartina 2005). These results indicate that the two varieties had performed very well in the two growing locations in Manggarai District despite their different performances over the two locations.

Mean seed yields per-ha of other five superior varieties were $1.16 \mathrm{t} \mathrm{ha}^{-1}$ (Betet), $1.51 \mathrm{t} \mathrm{ha}^{-1}$ (Perkutut), $1.33 \mathrm{t} \mathrm{ha}^{-1}$ (Kutilang), $1.26 \mathrm{t} \mathrm{ha}^{-1}$ (Walet), and $1.54 \mathrm{t} \mathrm{ha}^{-1}$ (Kenari) while the mean seed yields of these varieties according to their varietal description are, respectively, $1.5 \mathrm{t} \mathrm{ha}^{-1}$ (Betet), $1.5 \mathrm{t} \mathrm{ha}^{-1}$ (Perkutut), $1.13 \mathrm{t} \mathrm{ha}^{-1}$ (Kutilang), $1.7 \mathrm{t} \mathrm{ha}^{-1}$ (Walet), and $1.38 \mathrm{t} \mathrm{ha}^{-1}$ (Kenari) (Suhartina 2005). These results show that mean seed yield performance of Perkutut in this trial was similar to that of its varietal description while that of Kutilang and Kenari were higher than their respective varietal descriptions. Betet and Walet, on the other hand, performed poorly with much lower seed yield as compared to that in their varietal descriptions. Meanwhile, mean seed yield of Local Manggarai over two locations was only about $0.81 \mathrm{t} \mathrm{ha}^{-1}$, which was much lower than the superior varieties. The above descriptions demonstrate that each genotype behaved differently in their yield performances depending on their genetic backgrounds and the environments where these genetic factors are expressed. Welsh and Mogea (1991) stated that each crop genotype possesses a physiologically unique production capacity that is determined by genetic factors, which through its interaction with environmental factors such as energy (sunlight intensity), climate, soil nutrients, humidity, and other growth factors will develop the crops growth and yield performances. The effect of the environmental elements such as sunlight intensity, especially the UV-B radiation, on mungbean genotypes has also been examined by Choudhary and Agrawal (2014), who observed diverse morphological and physiological changes including the hormonal regulations in the mungbean genotypes.

By location, the present study results revealed that mean seed yield plot ${ }^{-1}$ of all genotypes was $1.9 \mathrm{t} \mathrm{ha}^{-1}$ at Watu Baur but only $0.91 \mathrm{t} \mathrm{ha}^{-1}$ at Perak. If one has to choose which location to extend the planting area in the region for the purpose of increasing the mungbean production, then the low altitude locations such as Watu Baur, etc. are the more favorable conditions to select for although the medium altitude regions can still be used as mungbean growing centers by utilizing superior varieties such as Murai and Vima-1, which, in the present study, produced a reasonable seed yield (over $1 \mathrm{t} \mathrm{ha}^{-1}$ ) in this location. Murai and Vima-1 are, therefore, recommended for extensive cultivation in Manggarai District at either Perak or Watu Baur or other locations to increase the mungbean productivity in the region.

A number of conclusions are drawn from the present study results as follows: (i) Most of the variables we observed in the present study were influenced by interaction between genotype and environment, except plant heights at flowering and harvesting stages, productive branches plant $^{-1}$, and 100-seed weight. (ii) The shortest harvesting date genotype at both locations was Vima-1 ( 59 DAP) while the best performers in number of productive branches plant ${ }^{-1}$, number of pods plant ${ }^{-1}$, seed yield plant ${ }^{-1}$ and seed yield plot $^{-1}$ in both locations were Murai and Vima-1. (iii) In addition to Betet and Kenari, Murai and Vima-1 also performed the best in number of pod clusters plant ${ }^{-1}$ in both locations. (iv) The highest number of pod plant ${ }^{-1}$ was produced by Vima-1, Murai, Betet, Walet, and Perkutut while the highest pod weight plant $^{-1}$ was obtained from Murai, Vima-1, and Kenari at Watu Baur. Meanwhile, Kutilang produced the highest 100-seed weight in both Perak and Watu Baur. (v) The highest mean seed yield over two locations was produced by Murai (991.87 $\mathrm{g} \mathrm{plot}^{-1}$, equals to $2.48 \mathrm{t} \mathrm{ha}^{-1}$ and Vima-1 (967.90 $\mathrm{g} \mathrm{plot}^{-1}$, equals to $2.42 \mathrm{t} \mathrm{ha}^{-1}$ ). (vi) Mean seed yield of all genotypes at Perak was $365.0 \mathrm{~g}$ plot $^{-1}$ (equals to $0.91 \mathrm{t}$ $\mathrm{ha}^{-1}$ ) while that in Watu Baur was $761.27 \mathrm{~g} \mathrm{plot}^{-1}$ (equals to $1.90 \mathrm{t} \mathrm{ha}^{-1}$ ).

\section{ACKNOWLEDGEMENTS}

This study was conducted with funding support from Badan Perencanaan dan Pembangunan Daerah (Bappeda) of Manggarai District, Indonesia. We thank the Head of Bappeda of Manggarai District for the funding support.

\section{REFERENCES}

Alia, Khalil IH, Ahmad F. 2014. Heritability estimate of yield related traits in mungbean at two locations. J Biol Agric Healthcare 4 (15): 120-124.

Allard RW. 1992. Plant Breeding. Translated by Manna. PT. Rhineka Cipta, Jakarta [Indonesian].

Aparna R, Singh SK, Sharma V, Pathak R. 2012. Stability and environmental indices analyses for yield attributing traits in Indian Vigna radiata genotypes under arid conditions. Asian J Agric Sci 4 (2): 126-133. 
Chand R, Pal C, Singh V, Chouwadappa P. 2015. Draft genome sequence of Cercospora canescens: A leaf spot causing pathogen. Curr Sci 109 2103-2110. DOI: 10.18520/v109/i11/2103-2110

Choudhary KK, Agrawal SB. 2014. Cultivar specificity of tropical mung bean (Vigna radiata L.) to elevated ultraviolet-B: Changes in antioxidative defense system, nitrogen metabolism, and accumulation of jasmonic and salicylic acids. Environ Exp Bot 99: 122-132. DOI: 10.1016/j.envexpbot.2013.11.006

ENT Central Bureau of Statistics. 2012. East Nusa Tenggara in Figures. East Nusa Tenggara Central Bureau of Statistics. Kupang. Indonesia.

Gnanaraj M, Udhayakumar N, Gandhi R, Manoharan K. 2015. Isolation and gene expression analysis of Phospholipase $\mathrm{C}$ in response to abiotic stresses from Vigna radiata (L.) Wilczek. Indian J Exp Biol 53: 335-341.

Goldsworthy PR and Fisher NM. 1996. Physiology of Cultivated Tropical Crops. Gadjah Mada University Press, Yogyakarta. [Indonesian]

Graham PH, Vance CP, Van Boekel MA, Khetarpaul N, Grewal RB, Nout, MJ. 2015. Mung bean: technological and nutritional potential. Crit Rev Food Sci Nutr 55: 670-688. DOI 10.1080/10408398.2012.671202

Hakim L, Suyamto. 2012. Correlation among characters and path analyses between yield components with grain yield on mungbean (Vigna radiata (L) Wilczek)]. Berita Biologi 11 (3): 339-349. [Indonesian].

HanumanthaRao B, Nair RM, Nayyar H. 2016. Salinity and HighTemperature Tolerance in Mungbean [Vigna radiata (L.) Wilczek] from a Physiological Perspective. Front. Plant Sci 7: 957. DOI: 10.3389/fpls.2016.00957.

Keating JDH, Easdown WJ, Yang RY, Chadha ML, Shanmugasundaram S. 2011. Overcoming chronic malnutrition in a future warming world: the key importance of mungbean and vegetable soybean. Euphyitica 180: 129-141. DOI: 10.1007/s10681-011-0401-6
Kumar P, Chand R, Singh V, Pal C. 2017. In vitro screening of calli of mungbean to cercosporin, a photoactivated toxin. Indian J Exp Biol 55: 113-121.

Om V, Singh AK. 2016. Analysis of morphological characters interrelationships in germplasm of mungbean [Vigna radiata (L.) Wilczek]. Legume Res 39 (1): 14-10.

Parihar AK, Basandrai AK, Sirari A, Dinakaran D, Singh D, Kannan K, Kushawaha KPS, Adinarayan M, Akram O, Latha TKS, Paranidharan V, Gupta S. 2017. Assessment of mungbean genotypes for durable resistance to Yellow Mosaic Disease: Genotype by Environment interactions. Plant Breed 136: 94-100. DOI: 10.1111/pbr.12446

Raturi A, Singh SK, Sharma V, Pathak, R. 2012. Stability and environmental indices analyses for yield attributing traits in Indian Vigna radiata genotypes under arid conditions. Asian J Agri Sci 4 (2): 126133

Somta P, Chankaew S, Kongjaimun A, Srinives P 2015. QTLs controlling seed weight and days to flowering in mungbean. Agrivita 38 (2): 159168. DOI: 10.17503/agrivita.v37i2.578

Suhartina 2005 Varietal description of superior pulse and tuber crop varieties Indonesian Legume and Tuber Crops Research Institute Malang, East Java. [Indonesian]

Ullah H, Khalil IH, Khalil IA, Khattak GSS 2011Performance of Mungbean Genotypes Evaluated in Multi-Environmental Trials Using the GGE Biplot Method Atlas J Biotechnol 1 (1): 1-8. DOI: 105147/ajbtch20110024

VSN International 2009 GenStat $12^{\text {th }}$ Edition for Windows. VSN International Ltd. wwwvsnicouk

Welsh JR, Mogea JP 1991 Fundamentals of Plant Genetics and Breeding PT Erlangga, Jakarta. [Indonesian] 